\title{
Work Environment : How is It Influenced on Employee Performance?
}

\author{
Lusiana Tulhusnah $^{1 *}$, Puryantoro ${ }^{2}$, Rasidi $^{3}$ \\ ${ }^{1,3}$ Faculty of Economics, Abdurachaman Saleh University \\ East Java - Indonesia \\ ${ }^{2}$ Faculty of Agriculture, Abdurachaman Saleh University \\ East Java - Indonesia \\ * Corresponding author: \\ Email: lusianatulhusnah445@gmail.com
}

\begin{abstract}
.
The productivity of employee performance can be determined by the conditions of the work environment. This of course will affect the success of the agency in determining its goals. The research objective was to determine the effect of the work environment on the performance of the employees of Abdurachman Saleh University (Unars). Quantitative research methods with a population of 66 UNARS employees and saturated sampling technique so that the sample is also 66 respondents. The data used are primary and secondary data. The data were analyzed using t test, determinant test and simple regression model using SPSS 22. The results showed a simple regression model $Y=-2.7596+0.622 X$. Work environment $(X)$ has a significant effect on the performance of UNARS employees. The contribution of the work environment to employee performance is $38.7 \%$, which means that there is a significant influence relationsh
\end{abstract}

Keywords: Work Environment, Employee Performance, UNARS

\section{INTRODUCTION}

Humans are the factors that determine the success or failure of an organization to carry out various activities in order to achieve organizational goals. In order for human resources to support the achievement of organizational goals, the organization must utilize these human resources more effectively and efficiently with a tendency towards improving employee performance [1]. The success of an organization or agency is influenced by the individual performance of its employees, an organization will seek to improve the performance of its employees in the hope that organizational goals can be achieved. Internal administrative services often overlap and sometimes are delayed because employees are often absent or not in place during effective work times, resulting in less than optimal completion of tasks and responsibilities that they have to complete. This is due to the lack of a supervisory function by the agency leader.

One of them is a tertiary institution that was established with the aim of preparing students to become members of society who have academic and / or professional abilities who can apply, develop and disseminate science and arts and http://ijstm.inarah.co.id 
contribute to improve people's lives and enrich national life. Higher education is not just an educational institution but also an institution that bridges students (students) and the surrounding community, so that the knowledge gained in higher education can be beneficial not only for themselves but also for others. In order for higher education activities to run well, a university must have knowledgeable and highly skilled human resources and efforts to manage educational institutions as optimally as possible so that their performance increases. Good performance is optimal performance, namely performance that is in accordance with university standards and supports the achievement of higher education goals. In order to improve higher education performance, employee performance is the main thing in encouraging the improvement of the performance of a university. [2]

One of the factors that affect employee performance is the work environment, the lack of facilities and infrastructure at the University makes some employees feel inconvenient because they have to do various facilities and infrastructure. In addition, the problem of working relations between subordinates and subordinates and leaders is also a concern, because this work relationship will affect the work comfort of employees which will have an impact on performance and in turn will affect the performance of the agency

The work environment is something that greatly affects employees at work. This influence can be through situations, conditions, work relationships between employees and the equipment used at work [3]. The environment is an external force or institution that has the potential to affect the performance of an organization, the special environment and the general environment are two formulations of the work environment [4]. Where the special environment itself is an environment that is directly related to the goals to be achieved in an organization. Meanwhile, the general environment is anything that is external or outside the organization that tends to have the potential to influence an organization.

The work environment in agencies can have a positive and significant impact on employee performance [ 5 ]. This shows that the work environment in the agency has an effect of $43,56 \%$ on employee performance and $56.44 \%$ is influenced by other factors. [6] and [7]1 ingkungan work significant positive effect on performance. However, it is different from [ 8 ] who said that the work environment has no effect on performance.Based on this, this study aims to analyze the influence of the work environment on employee performance at Abdurachman Saleh Situbondo University (UNARS) .

\section{METHODS}

The research object is the employees at Abdurachman Saleh University Situbondo Jl. PB. Sudirman No. 07 - Situbondo. This research uses nonprobability sampling technique by means of total sampling or saturated sample is a sampling technique that is carried out by taking the entire population. The population of 
employees is 66 people who are sampled in this study. Data were collected by means of interviews, questionnaires and documentation. Independent Variable (X1) work environment and Dependent Variable (Y) Employee Performance. Data were analyzed by validity, reliability and multiple regression analysis.

\section{RESULT AND DISCUSSION}

\section{Instrument Validity Test}

In research, an instrument is said to be valid if it is able to measure what is being measured from the variables under study. The validity measurement was carried out by using the Pearson moment product formula and the significance level of 0.05 . Each item score is correlated with its total score. The results of the validity test carried out with the help of SPSS 22 can be seen in the following table :

Table 1. Instrument Validity Test Results

\begin{tabular}{lcccc}
\hline No. & $\mathbf{r}_{\text {count }}$ & $\mathbf{r}_{\text {table }}$ & Condition & Conclusion \\
\hline $\mathrm{X}_{11}$ & 0.356 & 0.3081 & $\mathrm{r}_{\text {count }}>\mathrm{r}_{\text {table }}$ & valid \\
$\mathrm{X}_{12}$ & -0.190 & 0.3081 & $\mathrm{r}_{\text {count }}<\mathrm{r}_{\text {table }}$ & invalid \\
$\mathrm{X}_{13}$ & 0.484 & 0.3081 & $\mathrm{r}_{\text {count }}>\mathrm{r}_{\text {table }}$ & valid \\
$\mathrm{X}_{14}$ & 0.845 & 0.3081 & $\mathrm{r}_{\text {count }}>\mathrm{r}_{\text {table }}$ & valid \\
$\mathrm{X}_{15}$ & 0.879 & 0.3081 & $\mathrm{r}_{\text {count }}>\mathrm{r}_{\text {table }}$ & valid \\
$\mathrm{Y}_{11}$ & 0.795 & 0.3081 & $\mathrm{r}_{\text {count }}>\mathrm{r}_{\text {table }}$ & valid \\
$\mathrm{Y}_{12}$ & 0.798 & 0.3081 & $\mathrm{r}_{\text {count }}>\mathrm{r}_{\text {table }}$ & valid \\
$\mathrm{Y}_{13}$ & 0.637 & 0.3081 & $\mathrm{r}_{\text {count }}>\mathrm{r}_{\text {table }}$ & valid \\
$\mathrm{Y}_{14}$ & 0.475 & 0.3081 & $\mathrm{r}_{\text {count }}>\mathrm{r}_{\text {table }}$ & valid \\
$\mathrm{Y}_{15}$ & 0.756 & 0.3081 & $\mathrm{r}_{\text {count }}>\mathrm{r}_{\text {table }}$ & valid \\
\hline
\end{tabular}

Source: Data processed from questionnaires

\section{Instrument Reliability Test}

Reliability test is used to determine the consistency of measuring instruments and to show the extent to which these measuring instruments can be trusted and relied on in research. In this study, the reliability test used the Crobach alpha formula with the help of SPSS 22 , then the calculated alpha results were interpreted in the $r$ value table. If the calculated alpha level $>0.60$ then the measuring instrument has a high level of reliability. The results of the SPSS output are as follows:

Table 2 . Instrument Reliability Test Results

\begin{tabular}{lc}
\hline Variable & Cronbach's neglected \\
\hline Work environment & 0.803 \\
Employee Performance & 0.845 \\
\hline
\end{tabular}

Source: Data processed from questionnaires

In the Cronbach Alpha column there are numbers 0.803 and 0.845 , which means that the reliability calculation results are greater than 0.60 so it can be concluded that the measuring instrument has a good level of reliability.

\section{Classic assumption test}

1. Normality test 
The normality test aims to test whether the regression model, confounding variables or residuals have a normal distribution

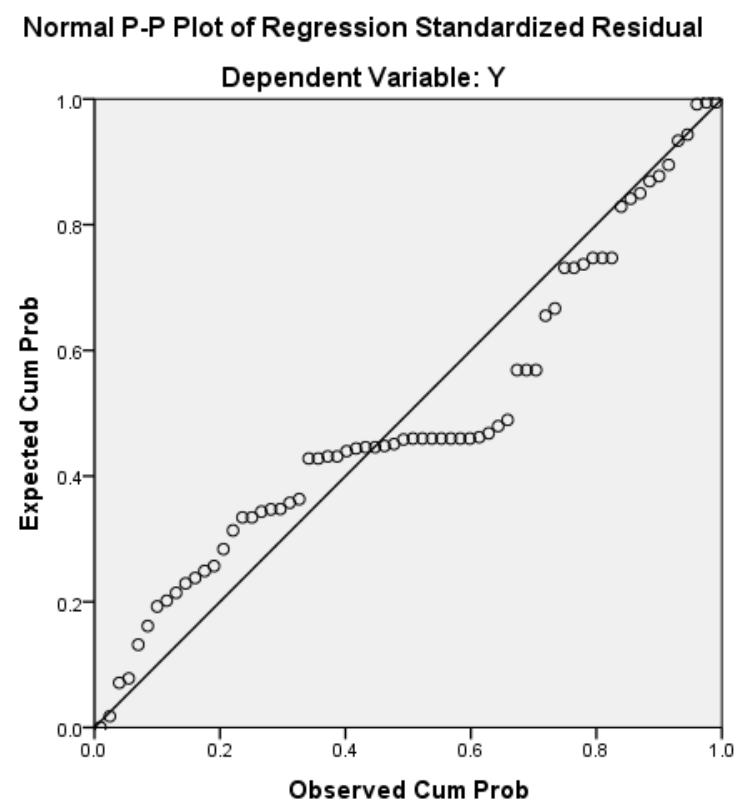

Figure 1 . Normality Test with P-Plot

From Figure 1 it can be seen that the distribution of the points around the line still follows a straight line and does not extend too far. So it can be concluded that the assumption model is in accordance with normality and the data is suitable for use.

Table 3 . Kolmogorov-Smirnov Test Normality Results

One-Sample Kolmogorov-Smirnov Test

\begin{tabular}{|ll|r|}
\hline N & & Unstandardized Residual \\
Normal Parameters ${ }^{\mathrm{a}, \mathrm{b}}$ & Mean & 66 \\
& Std. Deviation & .0000000 \\
Most Extreme Differences & Absolute & .78212757 \\
& Positive & .177 \\
& Negative & .177 \\
Statistical Test & & -104 \\
Asymp. Sig. (2-tailed) & & .177 \\
\hline
\end{tabular}

a. Test distribution is Normal.

b. Calculated from data.

c. Lilliefors Significance Correction.

Meanwhile, based on table 3, it is known that the statistical test is $0.177>0,05$ So it can be concluded that the assumption model is in accordance with normality and the data is suitable for use.

2. Multicollinearity Test

Multicollinearity test was conducted to determine the amount of intercolerance between independent variables in this study. If there is a correlation, then there is a multicollinearity problem. To detect the presence or absence of multicollinearity, it can 
be seen in the tolerance and VIF values. If the tolerance value is above 0,1 and the VIF value is below 10, multicollinearity does not occur. The multicollinearity test results for the regression model in this study are presented in the table below:

Table 4 . Multicollinearity Test Results

Coefficients ${ }^{\text {a }}$

\begin{tabular}{|c|c|c|c|c|c|c|c|}
\hline \multirow[b]{2}{*}{ Model } & \multicolumn{2}{|c|}{$\begin{array}{c}\text { Unstandardized } \\
\text { Coefficients }\end{array}$} & \multirow{2}{*}{$\begin{array}{c}\begin{array}{c}\text { Standardized } \\
\text { Coefficients }\end{array} \\
\text { Beta }\end{array}$} & \multirow[b]{2}{*}{$\mathrm{t}$} & \multirow[b]{2}{*}{ Sig. } & \multicolumn{2}{|c|}{$\begin{array}{c}\text { Collinearity } \\
\text { Statistics }\end{array}$} \\
\hline & B & Std. Error & & & & Tolerance & VIF \\
\hline $1 \quad$ (Constant) & $-2.572 \mathrm{E}-16$ & .098 & & .000 & 1,000 & & \\
\hline $\mathrm{X} 1$ & .609 & .106 & 609 & 5,755 & .000 & .867 & 1,153 \\
\hline
\end{tabular}

a. Dependent Variable: Y

Source: Data processed by SPSS 22, 2020

Based on table 4 above, the calculation of the VIF value for the Work Environment $(\mathrm{X})$ is 1.153 . This shows that there is no single independent variable that has a VIF value of more than 10, so it can be said that there is no multicollinearity between the independent variables in the regression model. The calculation results also show the tolerance value for each variable, namely work environment of 0.867 . This means showing that there is no independent variable that has a tolerance value is less than 0,1 . Then it can be concluded that there is no multicollinearity from the tolerance assessment in the regression model

3. Heteroscedasticity Test

The heteroscedasticity test aims to test whether in the regression model there is an inequality of variance from the residuals of one observation to another. If the residual variance from one observation to another observation remains, it is called homocedacity and if it is different it is called heteroscedasticity. Heteroscedasticity test graphically or heteroscedasticity scatterplot test is performed to see whether there is a certain pattern on the scatterplot graph.

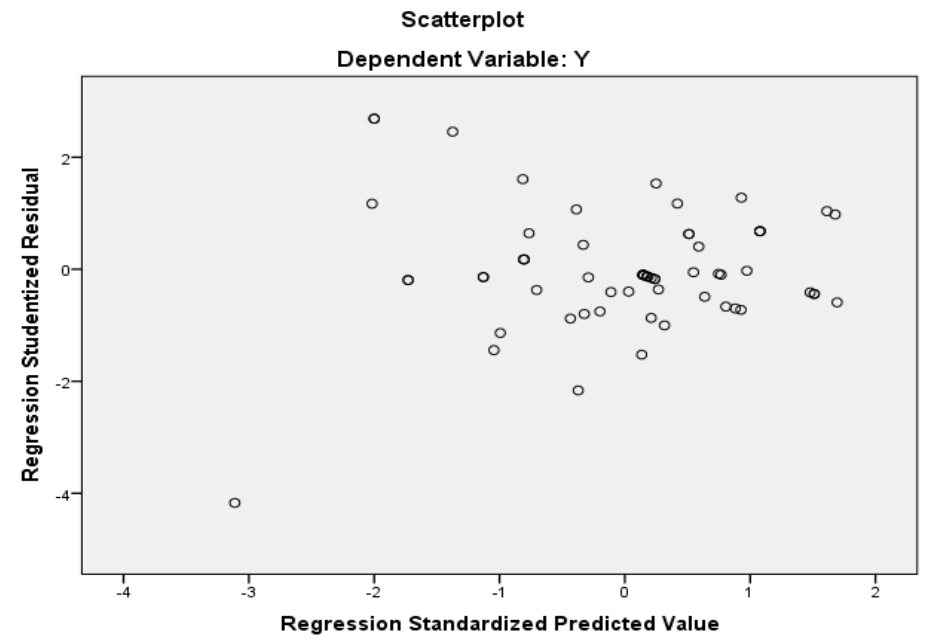

Figure 2 . The results of the scatterplot heteroscedasticity test Source: Data processed by SPSS 22, 2020

http://ijstm.inarah.co.id 
Based on Figure 2, it can be seen that the dots spread randomly and are spread both above and below the number 0 on the $\mathrm{Y}$ axis. This can be said that there is no heterkedasticity in the regression model.

The results of the heteroscedasticity test can also be shown by the Glejser test, which is a test that proposes to regress the residual absolute value of the independent variable.

Table 5 . Glejser Heteroscedasticity Test Results

\begin{tabular}{|ll|r|r|}
\hline & & \multicolumn{2}{|c|}{$\begin{array}{c}\text { Unstandardized } \\
\text { Residual }\end{array}$} \\
\hline X & Pearson Correlation & 1 & .000 \\
& Sig. (2-tailed) & & 1,000 \\
& $\mathrm{~N}$ & 66 & 66 \\
\hline Unstandardized Residual & Pearson Correlation & .000 & 1 \\
& Sig. (2-tailed) & 1,000 & \\
& $\mathrm{~N}$ & 66 & 66 \\
\hline
\end{tabular}

**. Correlation is significant at the 0.01 level (2-tailed).

Source: Data processed by SPSS 22, 2020

Based on table 5 above, it can be seen that the significance value of all independent variables $>0.05$ which is indicated by the significance value of the work environment $(\mathrm{X})$ is 1,000 . So it can be concluded that there is no heteroscedasticity.

\section{The Effect of Work Environment on Employee Performance}

Based on the results obtained from the regression coefficient in table 6, a regression equation can be made as follows:

$\mathrm{Y}=-2,7596+0,622 \mathrm{X}$

Where :

$\mathrm{Y}=$ Employee Performance

$\mathrm{X}=$ Work Environment

Table 6. Multiple Regression Coefficient Value

\begin{tabular}{|c|c|c|c|c|c|}
\hline \multirow[b]{2}{*}{ Model } & \multicolumn{2}{|c|}{ Unstandardized Coefficients } & $\begin{array}{l}\text { Standardized } \\
\text { Coefficients }\end{array}$ & \multirow[b]{2}{*}{$\mathrm{t}$} & \multirow[b]{2}{*}{ Sig. } \\
\hline & $\mathrm{B}$ & Std. Error & Beta & & \\
\hline $1 \quad$ (Constant) & $-2.596 \mathrm{E}-16$ & .097 & & .000 & 1,000 \\
\hline $\mathrm{X}$ & .622 & .098 & .622 & 6,358 & .000 \\
\hline
\end{tabular}

a. Dependent Variable: Y

Based on the calculation of SPSS 22 above it can be concluded as follows:

a. $-2,596$ is a constant number which means that if there is no work environment $(\mathrm{X})$, the consistent value of employee performance (Y) is approximately -2.596

b. The coefficient of work environment $(\mathrm{X})$ is 0,622 , which means that every $1 \%$ addition of work environment (X), employee performance (Y) will increase by $62.2 \%$.

Whether or not there is a significant influence between the independent variable on the dependent variable using the $t$ test. The $t$ statistical test shows the effect of one 
independent variable individually in explaining the variation of the dependent variable tested at a significance level of 0.05 .

Sig $<0.05$ or $\mathrm{t}$ count $>\mathrm{t}$ table then Ha is accepted, Ho is rejected Sig $>0.05$ or $\mathrm{t}$ count $<\mathrm{t}$ table then Ho is accepted, Ha is accepted

$\mathrm{t}$ count in the work environment $(\mathrm{X})$ is 6.358 while $\mathrm{t}$ table is 1.998 so that $\mathrm{t}$ count ( 6.358$)>\mathrm{t}$ table (1.998) and a significance value of $0.000<0.05$, so it can be concluded that $\mathrm{Ha}$ is accepted and Ho is rejected, meaning that work environment variables have a significant effect on employee performance.

The magnitude of the contribution of the influence of the leadership style on changes in employee performance using the coefficient of determination (R2) test

Table 7. Value of R Square

\begin{tabular}{|l|r|r|r|r|r|}
\hline Model & \multicolumn{1}{|c|}{$\mathrm{R}$} & R Square & \multicolumn{1}{c|}{$\begin{array}{c}\text { Adjusted R } \\
\text { Square }\end{array}$} & $\begin{array}{c}\text { Std. Error of the } \\
\text { Estimate }\end{array}$ & Durbin-Watson \\
\hline 1 & $.622 \mathrm{a}$ & .387 & .378 & .78894297 & 2,057 \\
\hline
\end{tabular}

a. Predictors: (Constant), X

b. Dependent Variable: Y

In Table 7 are the coefficient of determination $\mathrm{R}$ square number 0.387 , where the contribution of the work environment on the performance of employees at the University of Abdurachman Saleh by $38,7 \%$ correlation effect is quite significant .

The work environment is a means of supporting the smooth running of the work process, where the comfort and safety at work is also very much taken into account in creating a conducive and pleasant working atmosphere for employees so that it can support employee performance in carrying out their work activities. The work environment is also a series of conditions or conditions of the work environment of an agency which is the workplace of the employees who work in that environment.

The results showed that there was a significant influence between the work environment of Unars employees on performance [2] [9] and [11] saying that there was a significant influence between the work environment on employee work performance and the physical work environment had a positive effect on employee performance. This shows that the better the physical conditions of the work environment. Meanwhile [10] also explained that the work environment has a significant effect on job satisfaction in improving employee performance. However, the results of this study contradict [8] which states that the work environment has no effect on performance.

Based on the results of a questionnaire from respondents, they strongly agree with the index value of $85.15 \%$ with comfortable workspace conditions both from air ventilation, plants around the workplace, air condition (AC), room deodorizers provide comfort in working because they help eliminate odors that are annoying in the work environment. The observation results show that Unars employees feel comfortable because the room conditions are made with the facilities needed by the employees. The Unars neighborhood is right on the Pantura road Situbondo. 


\section{CONCLUSION}

Based on the results of research and discussion, it can be concluded that the work environment has a significant effect on the performance of Abdurachman Saleh Situbondo University employees. In addition, the contribution of the work environment to performance has a significant effect of $38.7 \%$. The findings in this study also indicate that the high and low performance of employees is influenced by the work environment. That is, if the work environment is getting better, the performance produced by employees will also be better.

\section{ACKNOWLEDGMENTS}

We would like to express our gratitute to the Ministry of Research and Technology/National Research and Innovation Agency for the funding opportunities that have been given to conduct this study. Apart from that, we extent our gratitude to the Institute of Research, Development and Community Service, Abdurachman Saleh Situbondo University for the directions in carrying out this study.

\section{REFERENCES}

[1] Wahyudi, A., \& Suryono, J. (2006). Analisis Pengaruh Gaya Kepemimpinan, Motivasi dan Lingkungan Kerja Terhadap Kinerja Pegawai. Jurnal Manajemen Sumber Daya Manusia, 1(1), 1-14.

[2] Parhusip, A. A., Alamsyah, V., \& Rahman, M. F. (2020). PENGARUH SEMANGAT KERJA, KEJELASAN PERAN, FISIK LINGKUNGAN KERJA TERHADAP KINERJA PEGAWAI DI UNIVERSITAS POTENSI UTAMA. Accumulated Journal (Accounting and Management Research Edition), 2(1), 01-14.

[3] Nanang Khosim, Z. A. (2018). PENGARUH INSENTIF, KEPEMIMPINAN, DAN LINGKUNGAN KERJA TERHADAP KEPUASAN KERJA KARYAWAN PADA RUMAH SAKIT UMUM DARMAYU PONOROGO (Doctoral dissertation, Universitas Muhammadiyah Ponorogo).

[4] Irawan, A.S. (2017). Pengaruh Kepuasan Kerja dan Komitmen Organisasi terhadap Turnover Intention. Jurnal Akutansi, Ekonomi dan Manajemen Bisnis. Vol.5, No.1, 105110.

[5] Budianto, A. A. T., \& Katini, A. (2017). Pengaruh lingkungan kerja terhadap kinerja pegawai pada PT Perusahaan Gas Negara (PERSERO) Tbk SBU Distribusi wilayah I Jakarta. KREATIF: Jurnal Ilmiah Prodi Manajemen Universitas Pamulang, 3(1).

[6] Permanasari, R. (2013). Pengaruh Motivasi Dan Lingkungan Kerja Terhadap Kinerja PT. Augrah Raharjo Semarang. Management Analysis Journal, 2(2).

[7] Dhermawan, A. A. N. B., Sudibya, I. G. A., \& Utama, I. W. M. (2012). Pengaruh motivasi, lingkungan kerja, kompetensi, dan kompensasi terhadap kepuasan kerja dan kinerja pegawai di lingkungan kantor Dinas Pekerjaan Umum Provinsi Bali. Jurnal Manajemen, Strategi Bisnis, dan Kewirausahaan, 6(2), 173-184.

[8] Arianto, D. A. N. (2013). Pengaruh kedisiplinan, lingkungan kerja dan budaya kerja terhadap kinerja tenaga pengajar. Jurnal Economia, 9(2), 191-200.

[9] Sofyan, D. K. (2013). Pengaruh Lingkungan Kerja Terhadap Kinerja Kerja Pegawai BAPPEDA. Industrial Engineering Journal, 2(1).

[10] Sugiarti, G. (2012). Pengaruh Lingkungan Kerja, Budaya Organisasi Dan Kompensasi Terhadap Kepuasan Kerja Untuk Meningkatkan Kinerja Pegawai (Studi Pada Fakultas Ekonomi Universitas 17 Agustus 1945 Semarang. Serat Acitya, 1(2), 73 
International Journal Of Science, Technology \& Management

[11] Runtunuwu, H. J., Lapian, J., \& Dotulong, L. (2015). Pengaruh Disiplin, Penempatan dan Lingkungan Kerja Terhadap Kinerja Pegawai Pada Badan Pelayanan Perizinan Terpadu Kota Manado. Jurnal EMBA: Jurnal Riset Ekonomi, Manajemen, Bisnis dan Akuntansi, 3(3).

http://ijstm.inarah.co.id 